\title{
KRATKA SKALA SUBJEKTIVNOG BLAGOSTANJA - NOVI INSTRUMENT ZA PROCENU POZITIVNOG MENTALNOG ZDRAVLJA
}

\author{
Veljko Jovanović' i Zdenka Novović
}

Odsek za psihologiju, Filozofski fakultet u Novom Sadu

Subjektivno blagostanje predstavlja jedan od najistraživanijih konstrukata u okviru pozitivne psihologije i jedan od najvažnijih indikatora pozitivnog mentalnog zdravlja. Važan zadatak istraživanja u ovoj oblasti je unapređenje postojećih $i$ konstrukcija novih mernih instrumenata za procenu subjektivnog blagostanja. U radu je predstavljen razvoj $i$ validacija Kratke skale subjektivnog blagostanja (KSB). Skala se sastoji od osam sta$v k i$, koje imaju visoku internu konzistentnost $(\alpha=0,86)$. Analiza glavnih komponenti je pokazala da se skala sastoji od dve dimenzije - afektivne (Pozitivan afektivitet) $i$ kognitivne (Pozitivan stav prema životu). Rezultati ukazuju da ove dve dimenzije predstavljaju različite aspekte subjektivnog blagostanja, ali da se u njihovoj osnovi nalazi opšti faktor subjektivnog blagostanja. U prilog konvergentne validnosti skale govore značajne pozitivne korelacije sa merama pozitivnog afekta, radosti i samouverenosti (SIAB-PANAS), kao i značajne negativne korelacije sa merama anksioznosti (STAI-T), depresivnosti (BDI-II) i negativnog afekta (SIAB-PANAS). U radu su date sugestije za buduća istraživanja, a takođe su prodiskutovane potencijalne prednosti skale, kao i mogućnosti primene u istraživačkoj $i$ kliničkoj praksi.

Ključne reči: pozitivna psihologija, subjektivno blagostanje, Kratka skala subjektivnog blagostanja, psihometrijske karakteristike

\footnotetext{
${ }^{1}$ E-mail: j.veljko@yahoo.com
} 


\section{Uvod}

Psihologija je od utemeljivanja krajem XIX veka, narednih stotinak godina mentalno zdravlje izučavala prevashodno iz ugla psihopatologije. Uvidom u teme kojima su se bavili članci objavljeni u psihološkim časopisima tokom dvadesetog veka, vidimo da je neuporedivo veći broj članaka koji se bave psihičkim poremećajima, nego onih u kojima su istraživani pozitivni aspekti ljudskog funkcionisanja. Posledica ovakve patocentrične orijentacije je postojanje ogromnog broja psiholoških instrumenata za procenu psihopatologije, i relativno mali broj instrumenata konstruisanih $u$ svrhe procene pozitivnog mentalnog zdravlja i fenomena poput nade, optimizma, zadovoljstva životom i sl.

Do promene fokusa u psihološkim istraživanjima dolazi u poslednjih desetak godina, sa razvojem pozitivne psihologije koja naglasak stavlja na proučavanje pozitivnih iskustava, osobina ličnosti i uslova koji omogućavaju čoveku da se razvija i optimalno funkcioniše (npr. Linley, Joseph, Harrington, \& Wood, 2006; Seligman \& Csikszentmihalyi, 2000; Snyder \& Lopez, 2002). U okviru pozitivne psihologije, jedan od najistraživanijih konstrukata predstavlja subjektivno blagostanje, fenomen koji najpoznatiji autori iz ove oblasti (kao što su Ed Diener, Sonya Lyubomirsky, Ruut Veenhoven, Martin Seligman, Daniel Nettle) izučavaju i pod terminom sreća. Decenijama je pojam sreće bio marginalizovan i etiketiran kao neakademski i tek nedavno je psihologija prihvatila činjenicu da je jedna od suštinskih karakteristika čoveka stremljenje ka sreći i iskustvu prijatnih emocija.

Koliko je traganje za srećom univerzalna karakteristika ljudi, ilustruju nalazi istraživanja koja pokazuje da u skoro svim kulturama u kojima su sprovođene studije, ljudi kao najvažniji cilj u životu navode postizanje sreće (Diener \& Oishi, 2000). Takođe, većina ljudi kao najvažniju vrednost u životu navodi sreću (Diener \& Oishi, 2004). Ove studije potvrđuju da ljudi kao osnovnu karakteristiku kvalitetnog života i mentalnog zdravlja ne vide neko neutralno stanje i odsustvo negativnih iskustava, već prisustvo prijatnih emocija i zadovoljstvo različitim domenima života. Da subjektivno blagostanje nije fenomen koji je jedino značajan na nivou pojedinca, odlično pokazuje činjenica da sreća i zadovoljstvo životom, pored ekonomskih i socijalnih indikatora, predstavljaju jedan od najvažnijih pokazatelja kvaliteta života određenog društva (Diener \& Suh, 1998).

Preteče empirijskih istraživanja blagostanja možemo naći u sociološkim studijama iz 1950-ih i 1960-ih godina koje su pojam sreće koristile kao subjektivni indikator kvaliteta života (Land, 1975, prema Keyes, Shmotkin, \& Ryff, 2002) i subjektivnu meru funkcionisanja društvenog sistema (Veenhoven, 2004). Jedan od prvih istraživača koji je ovoj temi pristupio na psihološki način, bio je Brad78 
burn (1969, prema Schimmack, 2008). On je definisao sreću kao ravnotežu između pozitivnog i negativnog afekta, koji predstavljaju dve nezavisne dimenzije. Posle toga su Andrews \& Withey (1976, prema Diener et al., 1999) sugerisali da blagostanje nije isključivo afektivni fenomen, već da obuhvata i poseban faktor zadovoljstva životom.

Diener (1984) je, sumirajući rezultate dotadašnjih istraživanja, definisao subjektivno blagostanje kao konstrukt koji čine tri komponente: zadovoljstvo životom, pozitivni afekat i nizak nivo negativnog afekta. Zadovoljstvo životom predstavlja kognitivni aspekt subjektivnog blagostanja i odnosi se na globalnu procenu osobe o tome kakav je njen život. Pozitivni afekat podrazumeva česta iskustva prijatnih emocija, a nizak nivo negativnog afekta retko doživljavanje neprijatnih emocionalnih stanja i relativno odsustvo osećanja depresivnosti i anksioznosti. Ovakva tripartitna struktura subjektivnog blagostanja je potvrđena u nizu istraživanja (npr. Lucas, Diener, \& Suh, 1996; Arthaud-Day, Rode, Mooney, \& Near, 2005). U skladu sa navedenom strukturom, subjektivno blagostanje se najčešće definiše kao kognitivna i afektivna evaluacija sopstvenog života (Diener, 2000).

Kako su rasla znanja o determinantama subjektivnog blagostanja i mehanizmima koji leže u njegovoj osnovi, kao važan zadatak pozitivne psihologije se nametnulo i unapređenje postojećih, ali i konstrukcija novih, kvalitetnih mernih instrumenata za procenu blagostanja.

U istraživanjima blagostanja i srodnih koncepata, koristi se nekoliko tipova instrumenata. U prvim istraživanjima, rađenim posle II svetskog rata, u svrhu ispitivanja javnog mnenja, sreća je procenjivana samo jednim pitanjem. Npr. u Galupovim istraživanjima od 1946. godine koristi se neka od varijacija pitanja ' $U$ celini gledano, koliko ste srećni?", na koje ispitanici odgovaraju na Likertovoj skali (Veenhoven \& Hagerty, 2006). Isti princip se koristi i u velikim nacionalnim studijama ispitivanja sreće i zadovoljstva životom. Iako je danas opšteprihvaćeno stanovište da je blagostanje multifacetni fenomen, postoje autori koji i u okviru psiholoških istraživanja koriste skale koje se sastoje od samo jedne stavke (npr. Abdel-Khalek, 2004) i navode da su ove mere validne i pouzdane (Abdel-Khalek, 2006). Sa druge strane, nalaze se autori koji tvrde da su jednoajtemske skale nepouzdane, i da procena blagostanja mora biti sveobuhvatna i uključivati različite aspekte (Diener \& Seligman, 2004).

Za procenu kognitivne komponente subjektivnog blagostanja, u istraživanjima se najčešće koriste dva tipa instrumenata: globalni i specifični. Globalne mere 
se odnose na generalnu procenu zadovoljstva životom i najpoznatija skala konstruisana u ove svrhe je SWLS (Satisfaction With Life Scale, Diener, Emmons, Larsen, \& Griffin, 1985). Drugi pristup nije zasnovan na proceni opšteg zadovoljstva, već se oslanja na procenu zadovoljstva u različitim domenima života, kao što su posao, brak, partnerski odnosi, zdravlje itd.

Za merenje afektivne komponente subjektivnog blagostanja, najčešće se koristi PANAS (Positive and Negative Affect Schedule, Watson, Clark, \& Tellegen, 1988). Ovaj instrument se koristi u većini istraživanja, jer meri dve dimenzije Pozitivni afekat i Negativni afekat, koje predstavljaju afektivnu komponentu subjektivnog blagostanja.

Među često upotrebljavanim skalama za procenu subjektivnog blagostanja su i DHS (Depression-Happiness Scale, Joseph \& Lewis, 1998), SHS (Subjective Happiness Scale, Lyubomirsky \& Lepper, 1999) i OHQ (Oxford Happiness Questionnaire, Hills \& Argyle, 2002).

Poslednjih godina, razvijeno je nekoliko inovativnih pristupa za procenu blagostanja, kao što su ESM ${ }^{2}$ (Experience Sampling Method, videti Scollon, KimPrieto, \& Diener, 2003) i DRM (Day Reconstruction Method, Kahneman, Krueger, Schkade, Schwarz, \& Stone, 2004). ESM i DRM teže da prevaziđu najveću manu klasičnih mera blagostanja - slabu ekološku validnost, i da specifičnom metodologijom procene omoguće da istraživač formira sliku o iskustvima osobe iz njenog svakodnevnog života. ESM je dizajniran tako da osoba sa sobom nosi mali računar koji tokom dana nasumično signalizira osobi da odgovori na pitanja ispisana na displeju, o tome šta trenutno radi, gde se nalazi, sa kim je, koliko uživa u tom trenutku i aktivnosti koju tada obavlja. Velika prednost ESM je to što smanjuje pristrasnosti pamćenja ispitanika i daje ekološki valjane informacije o kvalitetu i valenci emocionalnih doživljaja osobe tokom specifičnih aktivnosti i u različitim periodima dana. DRM je tehnika koja je osmišljena tako da osoba zapisuje u dnevnik sve epizode koje su joj se desile prethodnog dana, a zatim opisuje svaku epizodu tako što navodi kada je počela i kada se završila, šta je radila, gde je i sa kim bila. Nakon toga sledi afektivna evaluacija - osoba procenjuje na različitim afektivnim dimenzijama intenzitet doživljenih emocija tokom određenih epizoda.

U ovom radu će biti predstavljen razvoj Kratke skale subjektivnog blagostanja koja sadrži osam ajtema, kao i podaci o njenoj pouzdanosti i validnosti. Smatramo da postoji nekoliko razloga za konstrukciju ove skale. Naime, do sada je

\footnotetext{
${ }^{2}$ drugi naziv za ovaj metod je EMA (Ecological Momentary Assessment, Stone, Shiffman, \& DeVries, 1999).
} 
razvijeno nekoliko instrumenata koji predstavljaju globalnu meru sreće (kao što je SHS), kao i niz specifičnih skala kojima se procenjuju pojedinačni aspekti subjektivnog blagostanja (kao što su SWSL i PANAS). Sa druge strane, malo je pokušaja da se u jednom instrumentu objedine i afektivna i kognitivna komponenta. Jedna od osnovnih namena ovog istraživanja je provera psihometrijskih karakteristika skale koja bi bila korišćena u svrhe obuhvatnije procene subjektivnog blagostanja, odnosno instrumenta koji bi bio mera i afektivne i kognitivne evaluacije sopstvenog života.

Istraživanje ima i praktične implikacije, jer predstavlja početni korak u razvoju instrumenta, koji bi se koristio u svrhe procene subjektivnog blagostanja, kao jednog od najvažnijih indikatora pozitivnog mentalnog zdravlja. Danas je prihvaćeno stanovište da o mentalnom zdravlju pojedinca ne možemo zaključivati samo na osnovu odsustva psihopatoloških simptoma (merenih instrumentima kao što su BDI i SCL-90), već da je neophodno procenjivati i pozitivne aspekte funkcionisanja, kao što su zadovoljstvo životom i prisustvo prijatnih emocija. Instrumenti ovog tipa imaju značajnu primenu, ne samo u istraživanjima na nekliničkim uzorcima, već i u kliničkim i psihoterapijskim uslovima za procenu efekata tretmana. S obzirom da u našoj sredini (koliko nam je poznato) do sada nije konstruisan nijedan instrument za procenu subjektivnog blagostanja, smatramo da postoji potreba za empirijski validiranom skalom ovog tipa.

Najvažniji ciljevi ovog rada su: a) ispitivanje faktorske strukture Kratke skale subjektivnog blagostanja (KSB); b) ispitivanje psihometrijskih karakteristika konvergentne validnosti i pouzdanosti skale KSB.

\section{Metod}

\section{Uzorak}

Uzorak je činilo 234 studenata psihologije (197 ženskog i 37 muškog pola), sa Filozofskog fakulteta u Novom Sadu. Prosečna starost ispitanika je 21,4 godine ( $\mathrm{SD}=2,20$, raspon od 19 do 38 godina). 


\section{Instrumenti}

Kratka Skala Subjektivnog Blagostanja (KSB; Jovanović \& Brdarić, 2008). Razvoj skale: u prvoj fazi istraživanja, autori su definisali 19 stavki koje predstavljaju operacionalizaciju dva aspekta subjektivnog blagostanja - afektivnog i kognitivnog. Prilikom odabira stavki autori su se pridržavali kriterijuma fejs validnosti. Jedna grupa stavki se odnosi na iskustvo pozitivnih emocija (npr. Osećam se živahno), a druga na pozitivnu evaluaciju života (npr. Divno je živeti). Kognitivna komponenta subjektivnog blagostanja je definisana pomoću ajtema koji se odnose na generalno pozitivno vrednovanje života i optimističan stav prema životu. Ovakva operacionalizacija kognitivne komponente se razlikuje u odnosu na klasičnu, koja se oslanja na stavke koje obuhvataju zadovoljstvo sopstvenim životom, uslovima i postignutim ciljevima (kao što je slučaj u Skali zadovoljstva životom, Diener et al., 1985). Razlika u odnosu na postojeće mere kognitivne komponente subjektivnog blagostanja se sastoji u tome što konstruisani ajtemi, iako dominantno sadrže kognitivnu evaluaciju, obuhvataju i ostale komponente stava - emocionalnu i motivacionu. Smatramo da ovakva operacionalizacija može biti korisna, jer obuhvata više aspekata evaluacije i teorijski ima veću moć u predikciji ponašanja osobe od striktno kognitivne evaluacije.

Preliminarna verzija skale KSB od 19 stavki, primenjena je na uzorku od 141 ispitanika (prosečne starosti 23,25 godina), studenata Univerziteta u Novom Sadu. Nakon urađene analize glavnih komponenti, zadržane su stavke koje su na prvoj glavnoj komponenti imale najveća zasićenja. Zadržano je ukupno osam stavki sa zasićenjima iznad 0,70. Ovih osam stavki je imalo i najviše ajtem-total korelacije, koje su se kretale od 0,64 do 0,76. Interna konzistentnost skale od 8 stavki je u ovoj pilot studiji iznosila 0,89 (Kronbah $\alpha$ ), a prosečna inter-ajtem korelacija je bila 0,52 .

Nakon toga su proverene psihometrijske karakteristike skale od osam stavki, na uzorku od 234 ispitanika. Rezultati tog istraživanja će biti prikazani u ovom radu.

Beck Depression Inventory II, (BDI-II; Beck, Steer, \& Brown, 1996) je jedan od najpoznatijih i najčešće korišćenih instrumenata za procenu depresivnosti. Sastoji se od 21 skupa rečenica koje se odnose na različiti stepen prisustva simptoma depresivnosti. Zadatak ispitanika je da iz svakog skupa izabere jednu tvrdnju koja najbolje opisuje kako se osećao tokom protekle dve nedelje, koristeći skalu od 0 do 3. Maksimalan skor je 63. Prosečan skor ispitanika u ovom istraživanju je 6,59 $(\mathrm{SD}=6,25)$, a pouzdanost skale izražena Kronbahovom alfom iznosi 88 . 
State-Trait Anxiety Inventory (Form Y), (STAI-T; Spielberger, 1983) je Spilbergerov inventar za procenu anksioznosti, koji ima dve forme - za merenje anksioznosti kao stanja i crte. U ovom istraživanju je korišćena skala za merenje crte anksioznosti. Sastoji se od 20 stavki, na koje ispitanici odgovaraju na 4-stepenoj Likertovoj skali. Pouzdanost skale, dobijena u ovom istraživanju iznosi 0,88 $(\mathrm{M}=37,16, \mathrm{SD}=8,70)$.

Srpski Inventar Afekata Baziran na PANAS-X (SIAB-PANAS; Novović \& Mihić, 2008) je prevod i adaptacija na srpski jezik instrumenta PANAS-X, koji se koristi za procenu afekata (Positive and Negative Affect Schedule-X, Watson \& Clark, 1994). PANAS-X sadrži 60 stavki, odnosno prideva koji opisuju različita emocionalna stanja. Sastoji se od dve skale višeg reda (Pozitivni afekat i Negativni afekat) i 11 specifičnih skala koje se odnose na bazične negativne emocije (Strah, Hostilnost, Krivica, Tuga), bazične pozitivne emocije (Radost, Samouverenost, Pažnja) i tzv. ostala afektivna stanja (Stidljivost, Umor, Mir, Iznenađenje).

$\mathrm{U}$ ovom istraživanju su u analizu podataka, odnosno prilikom provere konvergentne validnosti skale KSB, uključene samo one skale SIAB-PANAS-a koje mere emocije koje predstavljaju sastavne komponente subjektivnog blagostanja - Pozitivni afekat $(\alpha=0,83)$, Negativni afekat $(\alpha=0,83)$, Radost $(\alpha=0,84)$ i Samouverenost $(\alpha=0,85)$. Ispitanici su imali instrukciju da na petostepenoj skali Likertovog tipa procene kako se generalno, tj. najčešće osećaju.

\section{Rezultati}

\section{Faktorska analiza skale}

Radi provere pretpostavke da skala KSB ima jedan generalni faktor subjektivnog blagostanja, na početku analize je ekstrahovana prva glavna komponenta skale, koja objašnjava $51,87 \%$ varijanse. Vrednosti zasićenja stavki prvom glavnom komponentom se kreću od 0,61 do 0,82.

Nakon toga je metodom glavnih komponenti, uz korišćenje Promax rotacije, utvrđena struktura skale. Na osnovu scree kriterijuma, izolovane su dve glavne komponente, koje ukupno objašnjavaju 66,55 \% varijanse (tabela 1). 
Tabela 1. Karakteristični koreni $i$ procenat objašnjene varijanse ekstrahovanih komponenti $(N=234)$

\begin{tabular}{ccccc}
\hline & \multicolumn{3}{c}{ Inicijalna solucija } & Rotirana solucija \\
\hline Komponenta & $\begin{array}{c}\text { Karakteristični } \\
\text { koren }\end{array}$ & $\begin{array}{c}\text { \% objašnjene } \\
\text { varijanse }\end{array}$ & Kumulativni \% & $\begin{array}{c}\text { Karakteristični } \\
\text { koren }\end{array}$ \\
\hline 1 & 4.150 & 51.87 & 51.87 & 3.488 \\
2 & 1.174 & 14.68 & 66.55 & 3.474 \\
\hline
\end{tabular}

U tabeli 2 je prikazana matrica sklopa izolovanih Promax komponenti.

Prvu komponentu su definisale stavke koje se odnose na iskustvo prijatnih emocija i sklonost dobrom raspoloženju. U skladu sa tim imenovana je kao Pozitivan afektivitet. Ovu komponentu definišu 4 stavke, sa zasićenjima koja se kreću od 0,726 do 0,928 .

Druga komponenta je nazvana Pozitivan stav prema životu. Određuju je 4 stavke koje odražavaju optimističan stav i pozitivno vrednovanje života. Faktorska zasićenja stavki su u rasponu od 0,738 do 0,903 .

Tabela 2. Matrica sklopa izolovanih komponenti u Promax rotaciji $(N=234)$

\begin{tabular}{lcc}
\hline Stavke skale KSB & $\begin{array}{c}\text { Pozitivan afekti- } \\
\text { vitet }\end{array}$ & $\begin{array}{c}\text { Pozitivan stav } \\
\text { prema životu }\end{array}$ \\
\hline 4. Osećam se živahno. & .928 & \\
3. Mnogo se smejem. & .808 & \\
5. Osećam da imam puno energije. & .764 & \\
7. Često se osećam radosno i ushićeno. & .726 & .903 \\
2. Sve u svemu, život je lep. & & .816 \\
8. Divno je živeti. & & .745 \\
1. Osećam da je život pun lepih iznenađenja. & & .738 \\
6. Život je pun dobrih prilika i mogućnosti. &
\end{tabular}

Legenda. $\mathrm{KSB}=$ Kratka skala subjektivnog blagostanja.

Korelacija između komponenti iznosi 0,55 . Ovaj rezultat pokazuje da dimenzije Pozitivnog afektiviteta i Pozitivnog stava prema života nisu redundantne i da mere različite aspekte subjektivnog blagostanja.

\section{Pouzdanost}

Pouzdanost skale KSB je proverena koeficijentima interne konzistencije. Rezultati pokazuju da cela skala od 8 stavki ima visoku pouzdanost $(\alpha=0,86)$. 
Takođe, pouzdanosti subskala su visoke (tabela 3), što pokazuje da komponente izolovane faktorskom analizom imaju adekvatnu internu konzistentnost.

Tabela 3. Deskriptivna statistika i interna konzistentnost subskala i ukupnog skora skale KSB $(N=234)$

\begin{tabular}{lccccc}
\hline & Min. & Max. & M & SD & Kronbah $\alpha$ \\
\hline Suma KSB & 18 & 40 & 33.04 & 4.52 & .86 \\
Pozitivan afektivitet & 6 & 20 & 15.50 & 2.84 & .83 \\
Pozitivan stav prema & 11 & 20 & 17.53 & 2.26 & .82 \\
životu & & & &
\end{tabular}

Legenda. $\mathrm{KSB}=$ Kratka skala subjektivnog blagostanja; Min. $=$ minimalan skor na $\mathrm{KSB}$; Max. = maksimalan skor na KSB; $\mathrm{M}=$ aritmetička sredina; $\mathrm{SD}=$ standardna devijacija; Suma KSB = ukupan skor na Kratkoj skali subjektivnog blagostanja.

Ajtem-total korelacije se kreću od 0,50 do 0,75 (tabela 4), sa prosečnom interajtem korelacijom od 0,46. Ovo ukazuje da skala ima zadovoljavajuću internu koherentnost, i da ajtemi imaju jedinstven predmet merenja.

Tabela 4. Ajtem-total korelacije stavki skale KSB $(N=234)$

Stavke skale KSB

Ajtem-total korelacije

1. Osećam da je život pun lepih iznenađenja. $\quad .66$

2. Sve u svemu, život je lep.

3. Mnogo se smejem.

4. Osećam se živahno. $\quad .67$

5. Osećam da imam puno energije. $\quad .59$

6. Život je pun dobrih prilika i mogućnosti.

7. Često se osećam radosno i ushićeno.

8. Divno je živeti.

Legenda. $\mathrm{KSB}=$ Kratka skala subjektivnog blagostanja.

\section{Validnost}

Da bismo procenili konvergentnu validnost skale KSB, ispitali smo njenu povezanost sa merama anksioznosti, depresivnosti i četiri skale SIAB-PANAS-a: Pozitivnim afektom, Negativnim afektom, Radošću i Samouverenošću (tabela $5)$. 
Tabela 5. Konvergentna validnost KSB skale - korelacije ${ }^{a}$ sa anksioznošću, depresivnošću, PA, $N A$, radošću i samouverenošću

\begin{tabular}{lccc}
\hline & $\begin{array}{c}\text { Pozitivan afektivi- } \\
\text { tet }\end{array}$ & $\begin{array}{c}\text { Pozitivan stav pre- } \\
\text { ma životu }\end{array}$ & Suma KSB \\
\hline STAI-T & -.62 & -.55 & -.66 \\
\hline BDI-II & -.48 & -.42 & -.51 \\
\hline SIAB-PANAS & & & -.42 \\
\hline NA & -.33 & -.44 & .66 \\
PA & .62 & .57 & .75 \\
Radost & .79 & .55 & .59 \\
Samouverenost & .56 & .50 & \\
\hline
\end{tabular}

Legenda. $\mathrm{N}=234$ za analize u kojima su korišćeni STAI-T i BDI-II; $\mathrm{N}=87$ za analize sa SIABPANAS-om;

KSB = Kratka skala subjektivnog blagostanja; STAI-T = State-Trait Anxiety Inventory-Trait verzija; BDI-II = Beck Depression Inventory-II; SIAB-PANAS = Srpski Inventar Afekata Baziran na PANAS-X; NA = Negativni afekat; PA = Pozitivni afekat.

${ }^{a}$ sve korelacije su značajne na nivou $\mathrm{p}<0,01$

Ukupan skor na skali KSB, kao i subskale Pozitivnog afektiviteta i Pozitivnog stava prema životu, imaju umerene do visoke negativne korelacije sa anksioznošću (STAI-T) i depresivnošću (BDI-II). Nešto viša korelacija sa anksioznošću je i očekivana, jer ajtemi koje sadrži STAI-T obuhvataju više aspekata negativnog afektiviteta, a ne samo anksioznost (Novović, Mihić, Tovilović, \& Jovanović, 2008).

Dobijena je umerena negativna korelacija subjektivnog blagostanja sa opštom dimenzijom Negativnog afekta, i umereno visoka pozitivna sa Pozitivnim afektom. Viša korelacija sa Pozitivnim afektom je očekivana, jer su sve stavke skale KSB definisane u pozitivnom smeru i ne sadrže markere negativnih emocija.

Da skala ima adekvatnu konvergentnu validnost, ukazuje i snažna povezanost subjektivnog blagostanja sa radošću $(r=0,75)$ i samouverenošću $(r=0,59)$. 


\section{Diskusija}

Skala za procenu subjektivnog blagostanja KSB je pokazala odlične psihometrijske karakteristike. Rezultati faktorske analize su pokazali da skala ima jedinstven predmet merenja. U osnovi svih osam stavki se nalazi generalni faktor subjektivnog blagostanja. Prednost skale je što iako poseduje unutrašnju koherentnost, ima i dve jasno izdvojene komponente - afektivnu (Pozitivan afektivitet) i kognitivnu (Pozitivan stav prema životu). Ove dve komponente se nalaze u umerenoj korelaciji, što ukazuje na to da nisu redundantne i da predstavljaju različite aspekte blagostanja.

Faktor Pozitivnog stava prema životu po sadržaju veoma podseća na koncept Ljubavi prema životu, koji je u pozitivnu psihologiju uveo Abdel-Khalek (2007). Autor ga definiše kao ,generalno pozitivan stav prema životu“" (Abdel-Khalek, 2007, str. 126). Ipak, ovaj konstrukt je još uvek nedovoljno istražen i nije sasvim jasno u kakvom odnosu stoji sa subjektivnim blagostanjem - da li je njegova sastavna komponenta ili ima specifične korelate i determinante. Iako namena ovog ovog istraživanja nije bila provera statusa ovog koncepta, dobijeni rezultati sugerišu da opšti stav osobe prema životu može biti informativan u kontekstu procene blagostanja. S obzirom da je ovakva konceptualizacija kognitivnog aspekta blagostanja različita u odnosu na tradicionalnu (koja je bazirana na proceni zadovoljstva osobe sopstvenim životom), smatramo da je neophodna dodatna provera njegove opravdanosti i korisnosti. Zadatak budućih istraživanja je da rasvetle prirodu ovog konstrukta i ispitaju da li ovakav novi pristup može pomoći boljem razumevanju subjektivnog blagostanja, što se postavlja kao jedan od osnovnih ciljeva prilikom konstrukcije novih instrumenata u ovoj oblasti (Kashdan, 2004). Jedna od pretpostavki za koju smatramo da je vredna provere u narednim istraživanjima, je da opšti stav prema životu predstavlja aspekt subjektivnog blagostanja koji je nezavisniji od uslova i stabilniji od zadovoljstva životom.

Celokupna skala kao i obe subskale imaju visoku pouzdanost, izraženu internom konzistentnošću skale.

Konvergentnu validnost skale dokazuju visoke pozitivne korelacije sa subskalama SIAB-PANAS-a koje se odnose na prijatne emocije (Radost i Samouverenost), kao i visoka pozitivna korelacija sa generalnom dimenzijom Pozitivnog afekta, koja se smatra sastavnom komponentom subjektivnog blagostanja (npr. Schimmack, 2008; Diener et al., 1999). Visoka korelacija sa radošću je očekivana, s obzirom da ova emocija predstavlja jednu od ključnih karakteristika po- 
zitivnog afekta (Egloff, Schmukle, Burns, Kohlmann, \& Hock, 2003). Naročito je indikativna visoka povezanost sa subskalom Samouverenost, koja je bliska konstruktu samopoštovanja. Naime, prethodna istraživanja su pokazala da je samopoštovanje jedan od najvažnijih korelata subjektivnog blagostanja (Cheng \& Furnham, 2003, Diener \& Diener, 1995, Schimmack, Oishi, Furr, \& Funder, 2004). Pojedini autori (npr. Argyle, 2001) sugerišu čak da se samopoštovanje može posmatrati kao sastavna komponenta sreće.

U prilog konvergentne validnosti skale govore i značajne negativne korelacije sa merama anksioznosti (STAI-T), depresivnosti (BDI-II) i Negativnim afektom. Depresivnost i anksioznost predstavljaju indikatore niskog subjektivnog blagostanja i mere distresa, tako da se često koriste za procenu konvergentne validnosti skala koje za predmet merenja imaju pozitivne aspekte mentalnog zdravlja (npr. Cammock, Joseph, \& Lewis, 1994; Lyubomirsky \& Lepper, 1997).

Kratka skala subjektivnog blagostanja pokazuje najslabiju povezanost sa opštom dimenzijom Negativnog afekta. Umerene negativne korelacije su verovatno posledica toga što su sve stavke koje sadrži KSB definisane u pozitivnom smeru i ne obuhvataju indikatore neprijatnih emocionalnih stanja. Pored toga, danas dominira stanovište po kojem pozitivni i negativni afekat nisu polovi jedne dimenzije, već predstavljaju relativno nezavisne komponente (npr. Schimmack, 2007). U skladu sa ovim stanovištem, niske negativne korelacije između Negativnog afekta i skale KSB u kojoj dominiraju stavke koje se odnose sa pozitivne emocije i pozitivan stav prema životu, razumljive su i očekivane.

Osim ohrabrujućih psihometrijskih karakteristika, smatramo da skala KSB ima i nekoliko kvaliteta koji je preporučuju za korišćenje u istraživanjima i praksi. Naime, prednosti skale KSB su njena kratka forma (sadrži samo osam ajtema) i jednostavnost primene. Ove karakteristike je čine pogodnom za ispitivanje subjektivnog blagostanja u longitudinalnim studijama (npr. dnevničkim istraživanjima), kao i za kontinuirana praćenja efekata psihoterapije. Tvrdnje su kratke i lako razumljive, tako da pretpostavljamo da je skala adekvatna i za primenu na ispitanicima sa niskim obrazovanjem, kao i za procenu subjektivnog blagostanja kod starih osoba.

Jedno od najvećih ograničenja ovog istraživanja je nereprezentativnost uzorka (samo studentska populacija) i neujednačenost po pitanju polne strukture. Buduća istraživanja bi trebalo da provere karakteristike skale na ispitanicima iz opšte populacije, uz vođenje računa o odnosu muških i ženskih ispitanika u uzorku. 
U narednim istraživanjima bi trebalo dodatno proveriti konvergentnu validnost skale, ispitivanjem povezanosti sa klasičnim merama subjektivnog blagostanja kao što je SWLS (Diener et al., 1985). Takođe, zbog provere valjanosti skale, korisno bi bilo ispitati relacije sa osobinama ličnosti, jer su ekstraverzija i neuroticizam dimenzije ličnosti koje su se u dosadašnjim istraživanjima pokazale kao najsnažniji personološki korelati subjektivnog blagostanja (pogledati metaanalizu DeNeve \& Cooper, 1998).

Instrumenti za procenu subjektivnog blagostanja imaju značajnu ulogu u savremenoj primenjenoj psihologiji, a naročito u oblasti mentalnog zdravlja. Uviđanje njihove važnosti je, pre svega, posledica proširenja koncepta mentalnog zdravlja, koje se danas posmatra ne samo kao odsustvo simptoma mentalnih bolesti, nego i kao prisustvo pozitivnih simptoma kao što su zadovoljstvo životom, sreća, lični razvoj, smisao života itd. (npr. Keyes, 2005). U kontekstu ovakve redefinicije, zaključke o mentalnom zdravlju pojedinca nije opravdano donositi samo na osnovu primene instrumenata za procenu psihopatoloških karakteristika, već je neophodna i procena prisustva indikatora pozitivnog funkcionisanja.

Iako su rezultati ovog istraživanja ohrabrujući i sugerišu da KSB predstavlja kvalitetnu meru subjektivnog blagostanja, na budućim istraživanjima je da provere da li ova skala može koristiti istraživačima i praktičarima i biti kvalitetno sredstvo za procenu pozitivnog mentalnog zdravlja. 


\section{Reference}

Abdel-Khalek, A. M. (2004). Happiness among Kuwaiti college students. Journal of Happiness Studies, 5, 93-97.

Abdel-Khalek, A. (2006). Measuring happiness with a single-item scale. Social Behavior and Personality, 34, 139-150.

Abdel-Khalek, A. M. (2007). Love of life as a new construct in the well-being domain. Social Behaviour and Personality, 35, 125-134.

Argyle, M. (2001). The psychology of happiness (2nd ed.). London: Routledge.

Arthaud-Day, M. L., Rode, J. C., Mooney, C. H., \& Near, J. P. (2005). The subjective well-being construct: a test of its convergent, discriminant, and factorial validity. Social Indicators Research, 74, 445-476.

Beck, A. T., Steer, R. A., \& Brown, G. K. (1996). Manual for the Beck Depression Inventory-II. San Antonio, TX: Psychological Corporation.

Cammock, T., Joseph, S., \& Lewis, C. A. (1994). Personality correlates of scores on the Depression-Happiness Scale. Psychological Reports, 75, 16491650 .

Cheng, H., \& Furnham, A. (2003). Personality, self-esteem, and demographic predictors of happiness and depression. Personality and Individual Differences, 34, 921-942.

DeNeve, K. M., \& Cooper, H. (1998). The happy personality: A meta-analysis of 137 personality traits and subjective well-being. Psychological Bulletin, 124, 197-229.

Diener, E. (1984). Subjective well-being. Psychological Bulletin, 95, 542-575.

Diener, E. (2000). Subjective well-being: The science of happiness, and a proposal for a national index. American Psychologist, 55, 34-43.

Diener, E., \& Diener, M. (1995). Cross-cultural correlates of life satisfaction and self-esteem. Journal of Personality and Social Psychology, 68, 653663.

Diener, E., \& Oishi, S. (2000). Money and happiness: Income and subjective well-being across nations. In E. Diener \& E. M. Suh (Eds.) Culture and subjective well-being (pp. 185-218). Cambridge, MA: MIT Press.

Diener, E., \& Oishi, S. (2004). Are Scandinavians happier than Asians? Issues in comparing nations on subjective well-being. In F. Columbus (Ed.) Asian 
Economic and Political Issues (Vol. 10, pp. 1-25). Hauppauge, NY: Nova Science Publishers.

Diener, E., \& Seligman, M. (2004). Beyond Money. Toward an Economy of Well-being. Psychological Science in the Public Interest, 5, 1-31.

Diener, E., \& Suh, E. (1998). Age and subjective well-being: An international analysis. Annual Review of Gerontology and Geriatrics, 17, 304-324.

Diener, E., Emmons, R. A., Larsen, R. J., \& Griffin, S. (1985). The Satisfaction With Life Scale. Journal of Personality Assessment, 49, 71-75.

Diener, E., Suh, E. M., Lucas, R. E., \& Smith, H. E. (1999). Subjective wellbeing: Three decades of progress. Psychological Bulletin, 125, 276-302.

Egloff, B., Schmukle, S. C., Burns, L. R., Kohlmann, C. W., \& Hock, M. (2003). Facets of dynamic positive affect: Differentiating joy, interest, and activation in the Positive and negative affect schedule (PANAS). Journal of Personality and Social Psychology, 85 (3), 528-540.

Hills, P., \& Argyle, M. (2002). The Oxford Happiness Questionnaire: A compact scale for the measurement of psychological well-being. Personality and Individual Differences, 33, 1073-1082.

Joseph, S., \& Lewis, C. A. (1998). The Depression-Happiness Scale: Reliability and validity of a bipolar self-report scale. Journal of Clinical Psychology, $54,537-544$.

Kahneman, D., Krueger, A. B., Schkade, D. A., Schwarz, N., \& Stone, A. A. (2004). A survey method for characterizing daily life experience: The day reconstruction method. Science, 306 (5702), 1776-780.

Kashdan, T. B. (2004). The assessment of subjective well-being (issues raised by the Oxford Happiness Questionnaire). Personality and Individual Differences, $36,1225-1232$.

Keyes, C. L. M. (2005). Mental illness and/or mental health? Investigating axioms of the complete state model of health. Journal of Consulting and Clinical Psychology, 73 (3), 539-548.

Keyes, C. L. M., Shmotkin, D., \& Ryff, C. F. (2002). Optimizing well-being: The empirical encounter of two traditions. Journal of Personality and Social Psychology, 82, 1007-1022. 
Linley, P. A., Joseph, S., Harrington, S., \& Wood, A. M. (2006). Positive psychology: Past, present, and (possible) future. The Journal of Positive Psychology, 1, 3-16.

Lucas, R. E., Diener, E., \& Suh, E. (1996). Discriminant validity of well-being measures. Journal of Personality and Social Psychology, 71, 616-628.

Lyubomirsky, S., \& Lepper, H. S. (1999). A measure of subjective happiness: preliminary reliability and construct validation. Social Indicators Research, 46, 137-155.

Novović, Z., \& Mihić, Lj. (2008). Srpski inventar afekata baziran na Positive and Negative Affect Schedule-X (SIAB-PANAS). Neobjavljeni manuskript, Novi Sad: Univerzitet u Novom Sadu.

Novović, Z., Mihić, Lj., Tovilović, S., \& Jovanović, V. (2008). Relations among positive and negative affect, dysphoria and anxiety. Psihologija, 4 (u štampi).

Schimmack, U. (2007). Methodological issues in the assessment of the affective component of subjective well being. In A. Ohn \& M. van Dulmen (Eds.) Handbook of methods in positive psychology (pp. 96-110). Oxford: Oxford University Press.

Schimmack, U. (2008). The structure of subjective well-being. In M. Eid, \& R. J. Larsen (Eds.) The science of subjective well-being ( $p p$. 97-124). New York: Guilford Press.

Schimmack, U., Oishi, S., Furr, B. M., \& Funder, D. C. (2004). Personality and life satisfaction: A facet level analysis. Personality and Social Psychology Bulletin, 30, 1062-1075.

Scollon, C. N., Kim-Prieto, C., \& Diener, E. (2003). Experience sampling: Promises and pitfalls, strengths and weaknesses. Journal of Happiness Studies, 4, 5-34.

Seligman, M. E. P., \& Csikszentmihalyi, M. (2000). Positive psychology: An introduction. American Psychologist, 55, 5-14.

Snyder, C. R., \& Lopez, S. J. (2002). Handbook of positive psychology. New York: Oxford University Press.

Spielberger, C. D. (1983). State-Trait Anxiety Inventory (Form Y). Palo Alto, CA: Consulting Psychologists Press.

Stone, A. A., Shiffman, S. S., \& DeVries, M. W. (1999). Ecological momentary assessment. In: E. Diener, N. Schwarz, \& D. Kahneman (Eds.) Well-being: 
the foundations of hedonic psychology (pp. 61-84). NewYork: Russell Sage Foundation.

Veenhoven, R., \& Hagerty, M. (2006). Rising happiness in nations 1946-2004. A reply to Easterlin. Social Indicators Research, 79, 421-436.

Veenhoven, R. (2004). Happiness as a public policy aim: The greatest happiness principle. In: A. Linley \& S. Joseph (Eds.) Positive psychology in practice (pp. 658-678). Hoboken, NJ: John Wiley \& Sons.

Watson, D., \& Clark, L. A. (1994). The PANAS-X: Manual for the positive and negative affect schedule-expanded form. Iowa City: University of Iowa.

Watson, D., Clark, L. A., \& Tellegen, A. (1988). Development and validation of brief measures of positive and negative affect: The PANAS scales. Journal of Personality and Social Psychology, 54, 1063-1070. 


\title{
ABSTRACT \\ THE SHORT SUBJECTIVE WELL-BEING SCALE - NEW INSTRUMENT FOR MEASUREMENT OF POSITIVE MENTAL HEALTH
}

\author{
Veljko Jovanović \& Zdenka Novović
}

Subjective well-being is one of the most investigated constructs in the field of positive psychology and one of the most important indicators of positive mental health. An important aim of research in this field is improvement and construction of new measures of subjective well-being. In this article we report on development and validation of the Short Subjective Well-Being Scale (KSB). This scale consists of 8 items, with high internal consistency $(\alpha=0,86)$. Principal components analysis showed that the scale measures two dimensions - affective (Positive Affectivity) and cognitive (Positive Attitude Towards Life). Results suggested that these two dimensions represent different aspects of subjective well-being, which are encompassed by a higher-order factor of subjective wellbeing. Our results supporting convergent validity of the scale were as follows: significant positive correlations with measures of positive affect, joviality, selfassurance (SIAB-PANAS), and significant negative correlations with measures of anxiety (STAI-T), dysphoria (BDI-II), and negative affect (SIAB-PANAS). Research, clinical, and practical implications of the findings were discussed.

Key words: : positive psychology, subjective well-being, Short Scale of Subjective Well-Being, psychometric characteristics 